\title{
PENGGUNAAN CACING TANAH (Lumbricus rubellus) SEBAGAI UMPAN ALTERNATIF PADA PANCING ULUR YANG DIOPERASIKAN MALAM HARI DI TELUK PALABUHANRATU
}

\author{
Mas Fariz Fitriyana ${ }^{1}$, Zulkarnain ${ }^{1}$, Roza Yusfiandayani ${ }^{1}$ dan Izza Mahdiana Apriliani ${ }^{2}$ \\ ${ }^{1}$ Departemen Pemanfaatan Sumberdaya Perikanan, Fakultas Perikanan dan Ilmu Kelautan, Institut Pertanian \\ Bogor \\ ${ }^{2}$ Departemen Perikanan, Fakultas Perikanan dan Ilmu Kelautan, Universitas Padjadjaran \\ *Korespondensi : zulkarnain_psp@yahoo.com
}

\begin{abstract}
Abstrak
Penelitian ini bertujuan untuk mengetahui komposisi hasil tangkapan ikan total, tangkapan ikan dominan, menganalisis pengaruh umpan cacing tanah yang dioperasikan malam hari dengan umpan yang biasa nelayan gunakan di Teluk Palabuhanratu dan menganalisis pengaruh perbedaan waktu penangkapan perjenis ikan dominan. Penelitian ini menggunakan metode uji coba penangkapan (experimental fishing) dengan 20 kali ulangan (trip). Komposisi hasil tangkapan terdiri atas 9 jenis ikan dengan jumlah total 201 ekor yang didominasi oleh ikan kuwe (Caranx sp) sebanyak 67 ekor atau 33.3\%, kakap (Lutjanus sp) sebanyak 26 ekor atau 12.9\%, kerapu (Epinephelus pachycentru) sebanyak 20 ekor atau 10.0\% dan terapon (Terapon jarbua) sebanyak 29 ekor. Perbandingan hasil tangkapan pancing ulur berbeda pada setiap perlakuan dengan menggunakan kedua jenis umpan. Pancing ulur dengan menggunakan umpan ikan tembang memberikan jumlah hasil tangkapan sebanyak 115 ekor atau 57.2\% dan menggunakan umpan cacing tanah sebanyak 86 ekor atau 42.8\%. kedua jenis umpan memberikan pengaruh nyata terhadap jumlah total hasil tangkapan dengan selang kepercayaan $95 \%$
\end{abstract}

Kata kunci : cacing tanah, malam hari, pancing ulur, umpan

\section{THE USE OF SOIL WAVES (Lumbricus rubellus) AS AN ALTERNATIVE BAIT ON HAND LINES THAT OPERATED NIGHT IN TELUK PALABUHANRATU}

\begin{abstract}
The research designed in order to determine the composition of the total fish catch, catch fish predominant, analyze the influence of worm bait operated night time with regular bait fishermen used in Palabuhanratu bay and analyze the effect of different time catching up with the dominant fish species. This research is implementing an experimental fishing with 20 trips. Composition of the catches is consisted by 9 species with total catches of 201 fishes and dominated by kuwe (Caranx sp) 67 fishes or 33.3\%, kakap (Lutjanus sp) with 26 fishes or 12.9\%, kerapu (Epinephelus pachycentru) with 20 or $10.0 \%$ and terapon (Terapon jarbua) with 29 or $14.4 \%$. Comparison of hand line catches is different by use of two bait types, hand line with sardines bait is giving result of catches by 115 fishes or $57.2 \%$ and using bait worm were 86 fishes or $42.8 \%$. The both of that bait has an significant effect on the total number of catches with $95 \%$ confidence interval.
\end{abstract}

Key words: earthworms, night, fishing rods extended, bait

\section{PENDAHULUAN}

Pancing ulur adalah salah satu alat tangkap yang umum dikenal oleh masyarakat luas, utamanya dikalangan nelayan. Pancing merupakan alat penangkapan ikan yang sederhana, tidak membutuhkan modal yang banyak untuk pengoprasianya, merupakan alat tangkap yang selektif karena penggunaan mata pancing digunakan sesuai dengan ukuran ikan dan termasuk alat tangkap yang ramah lingkungan. Jumlah alat tangkap pancing ulur pada tahun 2014 di PPN Palabuhanratu merupakan alat tangkap paling dominan penggunaannya dengan jumlah rata-rata 106 unit (PPN Palabuhanratu 2014).Faktor yang sangat berpengaruh penting dalam operasi penangkapan ikan menggunakan pancing ulur adalah umpan. Umpan merupakan salah satu alat bantu yang berpengaruh pada daya tarik dan rangsangan ikan (Gunarso 1985). Umpan merupakan salah satu bentuk rangsangan yang berbentuk fisika/kimiawi yang dapat memberikan respon terhadap ikan-ikan tertentu dalam tujuan penangkapan ikan (Ruivo 1982 dalam Hendrotomo1989).

$$
\text { Cacing tanah (Lumbricus rubellus) }
$$
merupakan hewan tingkat rendah yang tidak memiliki tulang belakang (avetebrata) dan bertubuh lunak. Hewan ini paling sering dijumpai di tanah dan tempat lembab yang banyak mengandung senyawa organik dan bahan mineral yang cukup baik dari alam maupun dari sampah limbah pembuangan penduduk sebagaimana habitat alaminya. Bagi sebagian orang cacing tanah masih dianggap mahluk yang menjijikan dikarenakan bentuknya, sehingga tidak jarang cacing masih dipandang sebelah mata. Terlepas dari hal tersebut, cacing masih dicari oleh sebagian orang untuk dimanfaatkan secara luas seperti penghasil pupuk organik, bahan pakan ternak, bahan baku obat, kosmetik, makanan dan minuman.

Beberapa penelitian yang telah dilakukan antara lain Zulkarnain (2012) yaitu, penggunaan umpan cacing tanah dengan menggunakan alat tangkap bubu lipat dengan jenis tangkapan lobster hijau (Panulirus versicolor), lobster hijau pasir 
(Panulirus homarus) dan lobster mutiara (Panulirus ornatus). Fazri (2014) Penggunaan umpan cacing tanah juga telah dilakukan penelitian dengan menggunakan alat tangkap pancing ulur pada waktu siang hari dengan hasil tangkapan ikan layang (Decapterus kurroides), swanggi (Priacanthus tayenus), kurisi (Nemipterus hexodon), kuwe (Caranx sp), barracuda (Sphyraena sp) dan pepetek (Leiognathus sp) yang dilakukan di teluk Palabuhanratu. Berdasarkan penelitian yang sudah dilakukan, maka diperlukan informasi keragaan alat tangkap pancing ulur dengan umpan cacing tanah yang dioperasikan pada malam hari.

Tujuan dari penelitian ini adalah untuk mengetahui komposisi hasil tangkapan ikan total pada alat tangkap pancing ulur, mengetahui hasil tangkapan ikan dominan pada alat tagkap pancing ulur, menganalisis pengaruh umpan cacing tanah (Lumbricus rubellus) pada alat tangkap pancing ulur (hand line) yang dioperasikan malam hari dengan umpan yang biasa nelayan gunakan di Teluk Palabuhanratu, serta menganalisis pengaruh perbedaan waktu penangkapan per jenis ikan dominan pada alat tangkap pancing ulur.

\section{METODE PENELITIAN}

Pengambilan data ini dilaksanakan pada bulan April 2016 yang bertempat di Teluk Palabuhanratu, Kabupaten Sukabumi, Provinsi Jawa Barat.

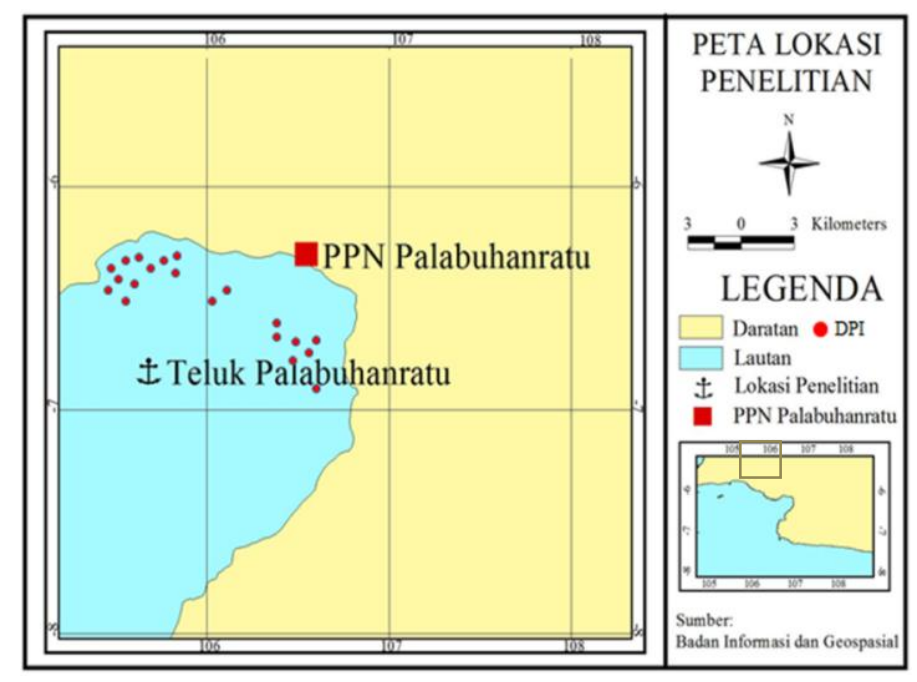

Gambar 1 Peta lokasi penelitian

Penelitian ini merupakan uji coba penangkapan ikan (experimental fishing) dengan melakukan kegiatan operasi penagkapan ini secara langsung di lapangan. Penelitian ini membandingkan hasil tangkapan alat tangkap pancing ulur (hand line) dengan diberi perlakuan berupa pemberian umpan standar yang biasa digunakan oleh nelayan misalnya umpan ikan tembang (Sardinella fimbriata) yang dibandingkan dengan umpan yaitu cacing tanah (Lumbricus rubellus).
Data yang dikumpulkan berupa data primer. Data primer diperoleh dengan cara melakukan pengamatan langsung di lapangan dengan melihat perbandingan hasil tangkapan dari kedua jenis umpan yaitu umpan ikan dan umpan alternatif cacing tanah yang digunakan. Data hasil tangkapan mencakup waktu penangkapan per trip, komposisi hasil tangkapan, jumlah, ukuran dan berat hasil tangkapan. Sebagai ulangan jumlah trip yang dilakukan sebanyak 20 trip dengan perlakukan secara bersamaan.

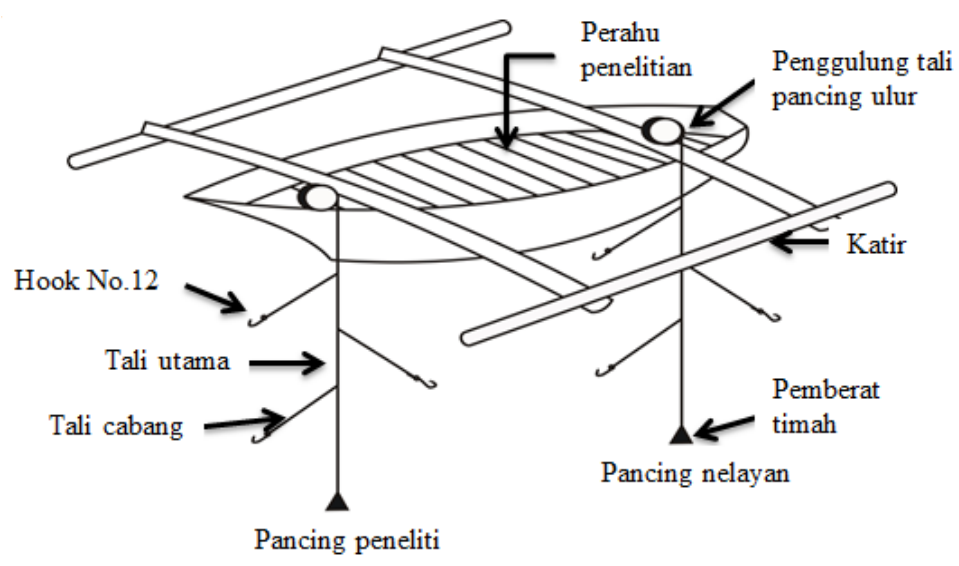

Gambar 2 Posisi pancing ulur penelitian diatas perahu 


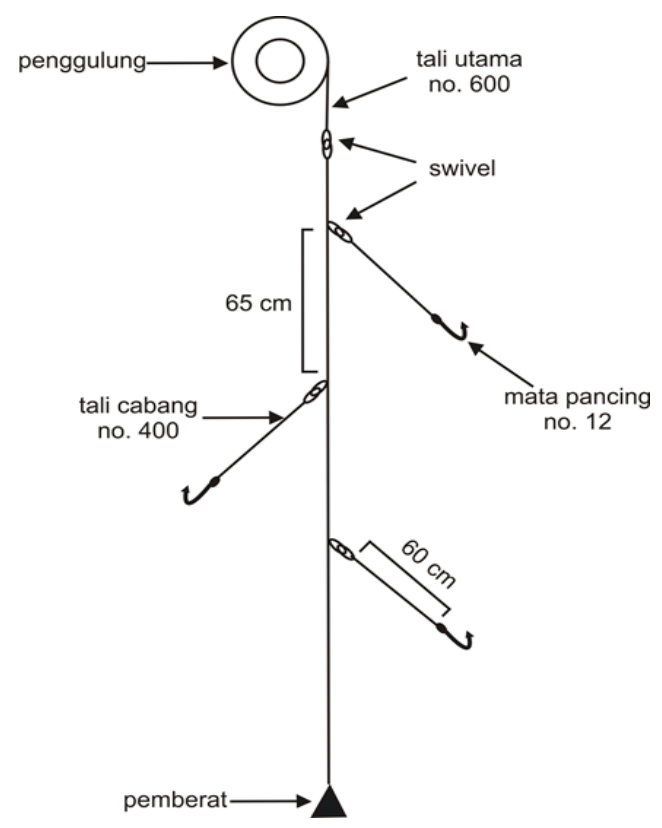

Gambar 3 Kontruksi alat tangkap pancing ulur

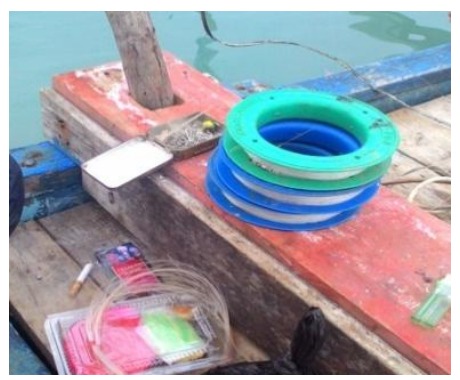

Pancing ulur yang digunakan

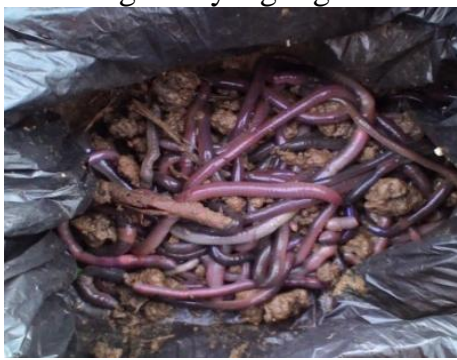

Cacing tanah

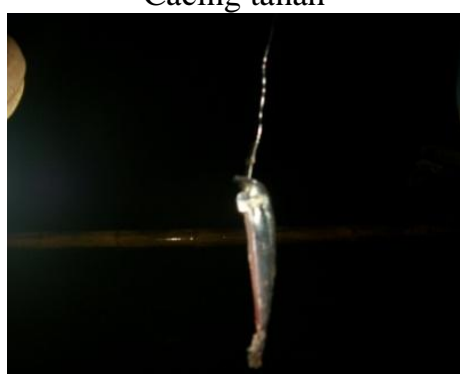

Umpan ikan tembang

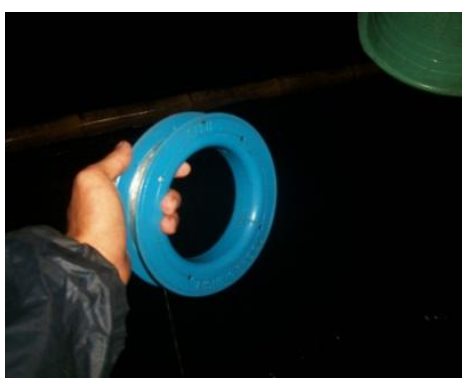

Setting malam hari

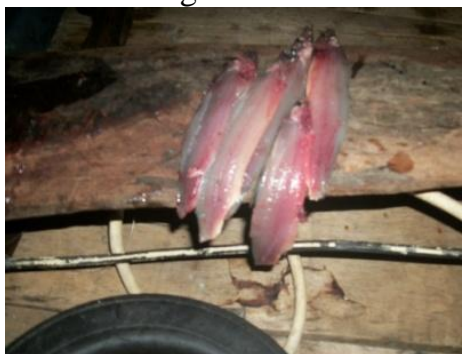

Sayatan ikan tembang

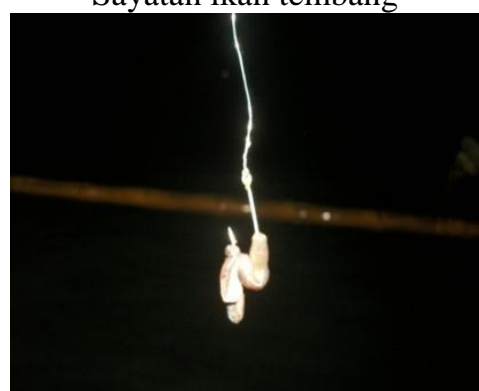

Umpan cacing tanah

Gambar 4 Penggunaan umpan cacing tanagh dan ikan tembang pada pancing ulur

Analisis yang dilakukan pada penelitian ini ada dua macam analisis, yaitu:

1. Analisis Deskriptif

Data hasil tangkapan disajikan dalam bentuk tabel beserta diagram, kemudian dianalisis secara deskriptif menurut pokok-pokok pembahasan seperti komposisi total hasil tangkapan pancing ulur, hasil tangkapan pancing ulur pada umpan yang berbeda dan jenis ikan dominan hasil 
tangkapan pada umpan yang berbeda dari 20 kali trip penangkapan.

2. Uji Statistik

Penelitian ini terdapat satu faktor yaitu umpan dengan dua macam perlakuan jenis umpan. Umpan dianggap dapat mempengaruhi komposisi hasil tangkapan baik jenis maupun jumlahnya. Uji statistik yang digunakan untuk mengetahui pengaruh perbedaan jenis umpan adalah uji $t$ (Walpole 1995). Uji $t$ dilakukan terhadap hasil tangkapan pancing ulur menggunakan umpan ikan tembang dan cacing tanah baik dari jumlah (ekor) ataupun berat total (kg) serta analisis terhadap ikan dominan. Uji $t$ yang dilakukan adalah uji $t$ berpasangan (paried $t$ - test) karena penelitian dilakukan secara bersamaan dalam satu perahu, dengan asumsi yang diterapkan selama penelitian adalah :

a. Ikan tujuan penangkapan menyebar merata atau menyebar normal diperairan.

b. Ikan tujuan penangkapan memiliki peluang yang sama untuk tertangkap pada kedua umpan.

Dasar keputusan yang akan diambil dalam uji $t$ adalah:

a. Jika $t$ hitung $>t$ tabel maka tolak $H O$, berarti perlakuan kedua jenis umpan memberikan pengaruh yang nyata terhadap hasil tangkapan.

b. Jika thitung < t tabel maka gagal tolak $H O$, perlakuan kedua jenis umpan tidak memberikan perlakuan yang nyata terhadap hasil tangkapan.

Hipotesis atau kesimpulan yang akan diambil :
HO

: Tidak terdapat pengaruh antara kedua umpan terhadap hasil

tangkapan.

H1 : Terdapat pengaruh antara kedua umpan terhadap hasil tangkapan.

Analisis dilakukan pada taraf $(\alpha)=0,05$.

Jumlah ulangan $(n)=20$ kali.

Nilai $\mathrm{t}$ dihitung sbb : $\mathrm{t}=\frac{\bar{x}_{1}-\bar{x}_{2}}{\sqrt{\frac{s_{1}^{2}}{n_{1}}+\frac{s_{2}^{2}}{n_{2}}}}$

Keterangan :

$$
\begin{array}{ll}
t & =\text { nilai } \text { thitung } \\
\mathrm{S} & =\text { simpangan baku } \\
n & =\text { ulangan } \\
\bar{x} 1 & =\text { rataan sampel kelompok } 1 \\
\bar{x} 2 & =\text { rataan sampel kelompok } 2
\end{array}
$$

\section{HASIL DAN PEMBAHASAN}

\section{Komposisi Total Hasil Tangkapan Pancing Ulur (Hand Line)}

Hasil tangkapan pancing ulur yang dioperasikan sebanyak 20 kali ulangan terdiri dari 9 jenis ikan hasil tangkapan, terrdiri dari ikan kuwe (Caranx sp), kakap (Lutjanus sp), kerapu (Epinephelus pachycentru), terapon (Terapon jarbua), kapas-kapas (Geres punctatus), kurisi (Nemipterus hexodon), Swanggi (Priacanthus tayanus), Sidat (Anguilla marmorata) dan selar bentrong (Selar crumenophthalmus). Total hasil

\begin{tabular}{|c|c|c|c|c|c|c|c|}
\hline \multirow{2}{*}{ No } & \multicolumn{3}{|c|}{ Jenis Ikan } & \multicolumn{2}{|c|}{ Jumlah } & \multicolumn{2}{|c|}{ Berat } \\
\hline & $\begin{array}{l}\text { Nama } \\
\text { Lokal }\end{array}$ & $\begin{array}{c}\text { Nama } \\
\text { Umum }\end{array}$ & $\begin{array}{c}\text { Nama } \\
\text { Latin }\end{array}$ & Ekor & $\%$ & $\mathrm{Kg}$ & $\%$ \\
\hline 1 & Kuwe & Kuwe & Caranx sp & 67 & 33.3 & 8.43 & 27.9 \\
\hline 2 & Kakap & Kakap & Lutjanus sp & 26 & 12.9 & 6.26 & 20.7 \\
\hline 3 & Kerapu & Kerapu & Epinephelus pachycentru & 20 & 10.0 & 2.90 & 9.6 \\
\hline 4 & Kerong-kerong & Terapon & Terapon jarbua & 29 & 14.4 & 3.38 & 11.2 \\
\hline 5 & Kakapasan & Kapas-kapas & Geres punctatus & 14 & 7.0 & 0.59 & 1.9 \\
\hline 6 & Boce & Kurisi & Nemipterus hexodon & 13 & 6.5 & 2.32 & 7.7 \\
\hline 7 & Camaul & Swanggi & Priacanthus tayanus & 7 & 3.5 & 1.53 & 5.1 \\
\hline 8 & Sidat & Sidat & Anguilla marmorata & 2 & 1.0 & 0.25 & 0.8 \\
\hline 9 & Bentong & Selar bentong & Selar crumenophthalmus & 23 & 11.4 & 4.52 & 15.0 \\
\hline & & Total & & 201 & 100 & 30.18 & 100 \\
\hline
\end{tabular}
tangkapan per individu ikan berjumlah 201 ekor dengan bobot total hasil tangkapan sebesar $30,18 \mathrm{~kg}$, dapat dilihat pada Tabel 2.

Tabel 2. Komposisi hasil tangkapan pancing ulur

\section{Komposisi Hasil Tangkapan Berdasarkan Jenis Umpan}

Tangkapan pancing ulur memiliki hasil yang berbeda-beda pada setiap umpan yang digunakan, umpan (A) yaitu umpan ikan tembang dan umpan (B) yaitu umpan cacing tanah. Jumlah hasil tangkapan pada setiap umpan disajikan pada tabel 3 . 
Tabel 3. Jumlah hasil tangkapan pada umpan yang berbeda

\begin{tabular}{rlrrrrrrrr}
\hline No & Jenis Ikan & \multicolumn{3}{c}{ Ikan Tembang (Umpan A) } & \multicolumn{3}{c}{ Cacing Tanah (Umpan B) } \\
\hline & & $\begin{array}{c}\text { Jumlah } \\
\text { (ekor) }\end{array}$ & \multicolumn{1}{c}{$\begin{array}{c}\text { Jumlah } \\
(\mathrm{kg})\end{array}$} & $\%$ & $\begin{array}{c}\text { Jumlah } \\
(\mathrm{ekor})\end{array}$ & $\%$ & $\begin{array}{c}\text { Jumlah } \\
(\mathrm{kg})\end{array}$ & $\%$ \\
\hline 1 & Kuwe & 49 & 42.6 & 6.59 & 36.8 & 18 & 20.9 & 1.84 & 15.0 \\
2 & Kakap & 8 & 7.0 & 2.58 & 14.4 & 18 & 20.9 & 3.68 & 30.0 \\
3 & Kerapu & 4 & 3.5 & 0.51 & 2.8 & 16 & 18.6 & 2.39 & 19.5 \\
4 & Terapon & 14 & 12.2 & 1.6 & 8.9 & 15 & 17.4 & 1.79 & 14.6 \\
5 & Kapas-kapas & 6 & 5.2 & 0.25 & 1.4 & 8 & 9.3 & 0.33 & 2.7 \\
6 & Kurisi & 8 & 7.0 & 1.42 & 7.9 & 5 & 5.8 & 0.91 & 7.4 \\
7 & Swanggi & 5 & 4.3 & 0.97 & 5.4 & 2 & 2.3 & 0.56 & 4.6 \\
8 & Sidat & 0 & 0.0 & 0 & 0.0 & 2 & 2.3 & 0.25 & 2.0 \\
9 & Selar bentong & 21 & 18.3 & 4.01 & 22.4 & 2 & 2.3 & 0.51 & 4.2 \\
\hline & Total & $\mathbf{1 1 5}$ & 100.0 & $\mathbf{1 7 . 9}$ & 100.0 & $\mathbf{8 6}$ & 100.0 & $\mathbf{1 2 . 3}$ & 100.0 \\
\hline
\end{tabular}

Kuwe (Caranx sp) adalah jenis ikan paling dominan tertangkap pada penelitian ini. Jumlah ikan kuwe yang tertangkap sebanyak 67 ekor $(33.3 \%)$ dari total hasil tangkapan dengan berat total $8,43 \mathrm{~kg}$ (27.9\%). Ikan hasil tangkapan yang dominan lainnya adalah ikan terapon (Terapon jarbua) dengan jumlah hasil tangkapan sebanyak 29 ekor (14.4\%) dengan berat total $3,38 \mathrm{~kg}(11.2 \%)$. Ikan yang dominan selanjutnya adalah kakap (Lutjanus sp) sebanyak 26 ekor $(12.9 \%)$ dengan berat total sebesar $6,26 \mathrm{~kg}$ (20.7\%). Ikan selanjutnya adalah ikan selar bentong (Selar crumenophthalmus) dengan jumlah hasil tangkapan sebanyak 23 ekor (11.4\%) dengan berat total sebesar 4,52 kg (15.0\%). Ikan hasil tangkapan dominan yang terakhir yaitu ikan kerapu (Epinephelus pachycentru) dengan jumlah hasil tangkapan sebanyak 20 ekor $(10.0 \%)$ dengan berat total sebesar 2,90 kg (9.6\%). Beberapa jenis ikan hasil tangkapan lainnya secara berturut-turut adalah ikan kapas-kapas (Geres punctatus) sebanyak 14 ekor $(7.0 \%)$ dengan berat $0,59 \mathrm{~kg}(1.9 \%)$,ikan kurisi (Nemipterus hexodon) sebanyak 13 ekor (6.5\%) dengan jumlah berat $2,32 \mathrm{~kg}(7.7 \%)$, ikan swanggi sebanyak 7 ekor $(3.5 \%)$ dengan berat $1,53 \mathrm{~kg}(5.1 \%)$ dan yang terakhir ikan sidat (Anguila marmorata) sebanyak 2 ekor (1.0\%) dengan berat $0,25 \mathrm{~kg}(0.8 \%)$.

Berdasarkan komposisi hasil tangkapan diperoleh hasil tangkapan umpan ikan tembang lebih tinggi dibandingkan dengan umpan cacing tanah. alat tangkap pancing ulur yang menggunakan umpan ikan Tembang memberikan jumlah total hasil tangkapan sebanyak 115 ekor $(57.2 \%)$ dengan berat total 17,93 $\mathrm{kg}$ (59.4\%), sedangkan pancing ulur yang menggunakan umpan Cacing tanah memberikan jumlah total hasil tangkapan sebanyak 86 ekor $(42.8 \%)$ dengan berat total $12,26 \mathrm{~kg}(40.6 \%)$.

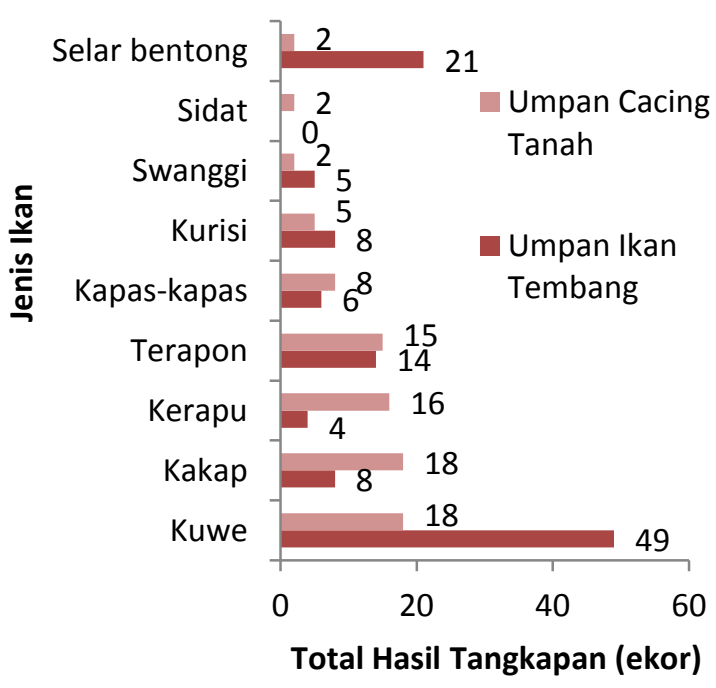

Gambar 5 Grafik total hasil tangkapan dalam (ekor) berdasarkan penggunaan jenis umpan

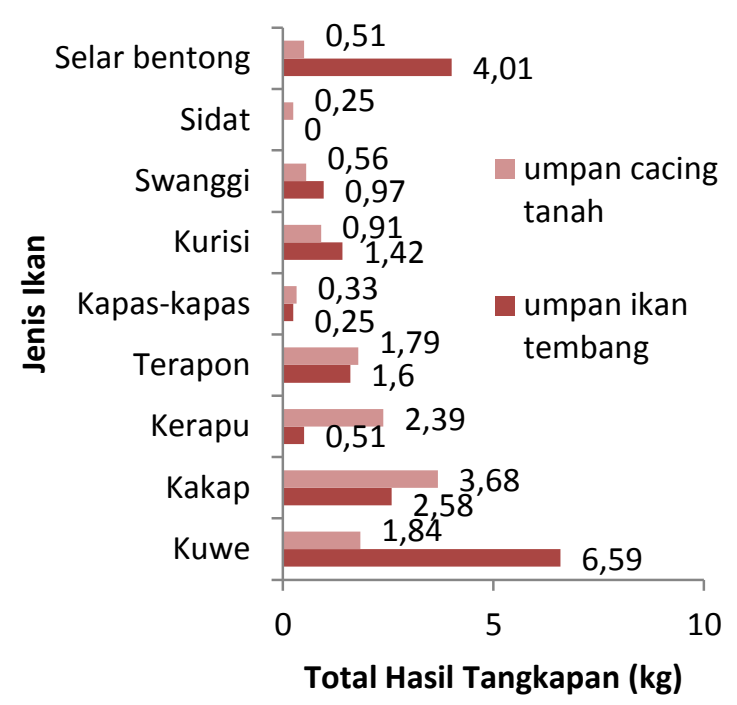

Gambar 6 Grafik total berat hasil tangkapan dalam $(\mathrm{Kg})$ berdasarkan penggunaan jenis umpan 


\section{Hasil Analisis Statistik Uji-t}

Berdasarkan analisis uji $t$ statistik pengaruh perbedaan kedua jenis umpan terhadap hasil tangkapan ikan (ekor) diperoleh nilai thit $>t t a b$ $(4,68>4,10)$. Hal ini menunjukkan bahwa perlakuan dari kedua jenis umpan yaitu umpan ikan tembang dan umpan cacing tanah memberikan pengaruh yang nyata terhadap jumlah total hasil tangkapan, sedangkan uji $t$ statistik pengaruh perbedaan kedua jenis umpan terhadap hasil tangkapan ikan $(\mathrm{kg})$ diperoleh nilai thit $<$ ttab $(3.03<4,10)$. Hal ini menunjukkan bahwa perlakuan dari kedua jenis umpan yaitu umpan ikan tembang dan umpan cacing tanah tidak memberikan pengaruh yang nyata terhadap jumlah total hasil tangkapan $(\mathrm{kg})$ pada selang kepercayaan $95 \%$.

\section{Hasil tangkapan Ikan Dominan pada Umpan yang Berbeda}

Berdasarkan hasil tangkapan pada alat tangkap pancing ulur menggunakan dua jenis umpan yang berbeda, diperoleh hasil tangkapan 4 jenis ikan dominan yaitu kuwe (Caranx sp), kakap (Lutjanus $s p)$, kerapu (Epinephelus pachycentru) dan terapon (Terapon jerboa) yang hasil tangkapannya lebih dominan dibandingkan hasil tangkapan ikan yang lainnya, ikan kuwe pada umpan ikan tembang memperoleh hasil tangkapan sebanyak 49 ekor dibandingkan dengan umpan cacing tanah yang berjumlah 18 ekor dengan nilai rata-rata hasil tangkapan (ekor) per trip \pm SE pada umpan ikan tembang adalah 2.45 ekor \pm 0.49 dan pada umpan cacing tanah adalah 0.85 ekor \pm 0.17 . Ikan kakap pada umpan ikan tembang memperoleh hasil tangkapan sebanyak 8 ekor dan pada umpan cacing tanah sebesar 18 ekor, dengan nilai rata-rata hasil tangkapan adalah 0.4 ekor \pm 0.13 pada umpan ikan tembang dan pada umpan cacing tanah adalah 0.9 ekor \pm 0.13 . Ikan kerapu pada umpan ikan tembang memperoleh hasil tangkapan sebanyak 4 ekor dan pada umpan cacing tanah sebanyak 16 ekor dengan nilai rata-rata hasil tangkapan pada umpan ikan tembang adalah 0.2 ekor \pm 0.11 dan pada umpan cacing tanah adalah 0,8 ekor \pm 0.11 dan yang terakhir adalah ikan terapon pada umpan ikan tembang memperoleh hasil tangkapan sebanyak 14 ekor dan pada umpan cacing tanah sebanyak 15 ekor dengan nilai rata-rata hasil tangkapan pada umpan ikan tembang adalah 0.7 ekor \pm 0.25 dan pada umpan cacing tanah adalah 0.75 ekor \pm 0.17 .

\section{Hasil Analisis Statistik Uji-t Berdasarkan Hasil Tangkapan Ikan Dominan}

Berdasarkan hasil analisis dengan menggunakan $u j i-t$ mengenai pengaruh kedua umpan terhadap 4 jenis hasil tangkapan ikan dominan, umpan ikan tembang dan umpan cacing tanah memberikan pengaruh secara nyata terhadap hasil tangkapan ikan kuwe (Caranx $s p$ ) dan ikan kakap (Lutjanus sp) didapatkan nilai thit secara berturutturut 4.23 dan 4.35 dengan ttab sebesar 4.10 dan 4.10. Ikan kerapu (Ephinepelus pachycentrus) dan terapon (Terapon jarbua) tidak memberikan pengaruh nyata terhadap kedua jenis umpan ikan tembang dan umpan cacing tanah dengan nilai thit sebesar 3.94 dan 0.29 dengan nilai ttab sebesar 4.10 dan 4.10 pada selang kepercayaan 95\%. Hasil analisis uji statistik dapat dilihat pada tabel 4.

Tabel 4 Uji $t$ statistik pengaruh umpan ikan tembang dan umpan cacing tanah terhadap hasil tangkapan ikan dominan (ekor).

\begin{tabular}{lcccl}
\hline \multicolumn{1}{c}{ Jenis Ikan } & Thit & Ttab & $\alpha$ & Hasil Analisis \\
\hline Kuwe & 4.23 & 4.10 & 0.05 & Berpengaruh nyata \\
Kakap & 4.35 & 4.10 & 0.05 & Berpengaruh nyata \\
Kerapu & 3.94 & 4.10 & 0.05 & Tidak berpengaruh nyata \\
Terapon & 0.29 & 4.10 & 0.05 & Tidak berpengaruh nyata \\
\hline
\end{tabular}

\section{Frekuensi Waktu Tertangkap Ikan}

1. Frekuensi waktu tertangkap ikan kuwe

Ikan kuwe memperoleh hasil tangkapan terbanyak pada pukul 19.00-00.00 WIB dengan nilai rata-rata $\pm \mathrm{SE}$ adalah 0.3 ekor \pm 0.11 pada umpan ikan tembang dan umpan cacing tanah tangkapan terbanyak pada pukul 19.00-00.00 WIB dengan nilai rata-rata \pm SE adalah $0.75 \pm 0.05$. 


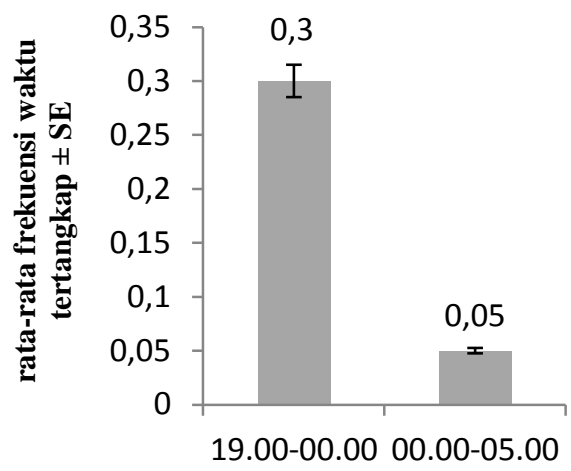

Waktu tertangkap

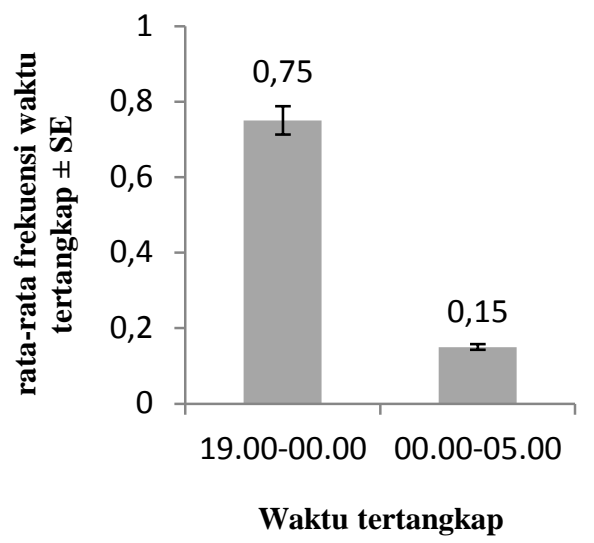

b. Umpan cacing tanah

Gambar 7 Frekuensi waktu tertangkapnya ikan kuwe dengan menggunakan umpan ikan tembang dan cacing tanah

2. Frekuensi waktu tertangkap ikan kakap

Ikan kakap memperoleh hasil tangkapan terbanyak pada pukul 19.00-00.00 dengan nilai ratarata \pm SE adalah 0.3 ekor \pm 0.11 pada umpan ikan

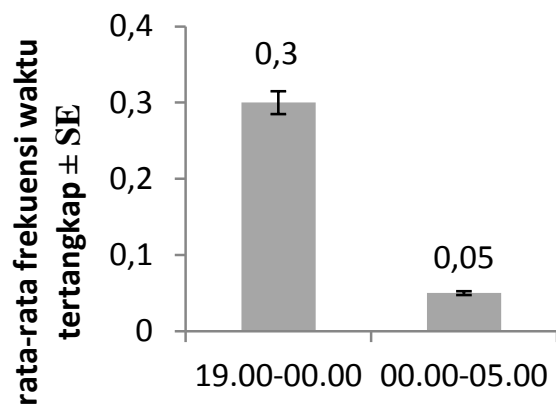

Waktu tertangkap

a. Umpan ikan tembang tembang dan umpan cacing tanah tangkapan terbanyak pada pukul 19.00-00.00 WIB dengan nilai rata-rata \pm SE adalah 0.75 ekor \pm 0.10 .

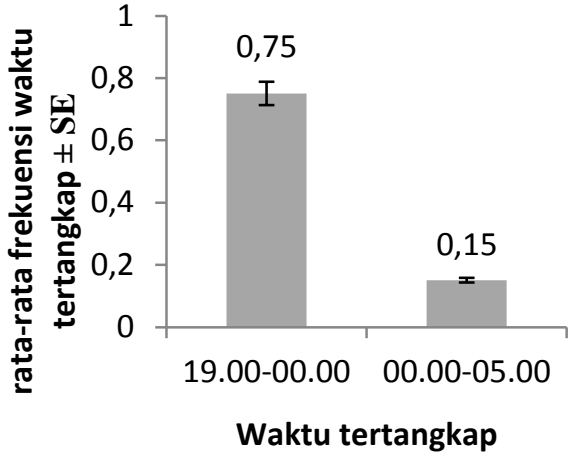

b. Umpan cacing tanah

Gambar 8 Frekuensi waktu tertangkapnya ikan kakap dengan menggunakan umpan ikan tembang dan cacing tanah

3. Frekuensi waktu tertangkap ikan kerapu

Ikan kerapu memperoleh hasil tangkapan sama banyak pada pukul 19.00-00.00 dan 00.0005.00 WIB dengan nilai rata-rata \pm SE adalah 0.1

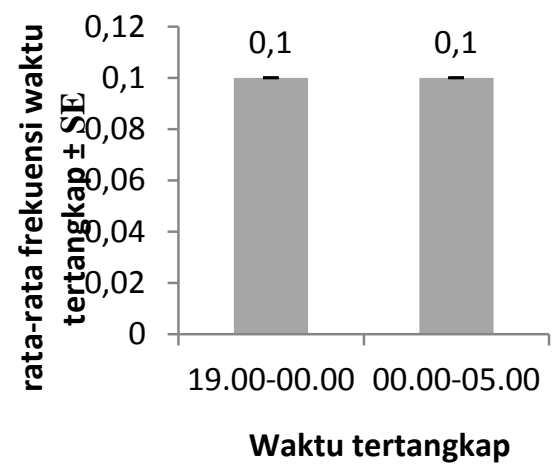

a. Umpan ikan tembang ekor \pm 0.07 pada umpan ikan tembang dan umpan cacing tanah tangkapan terbanyak pada pukul 19.0000.00 WIB dengan nilai rata-rata \pm SE adalah 0.65 ekor \pm 0.13 .

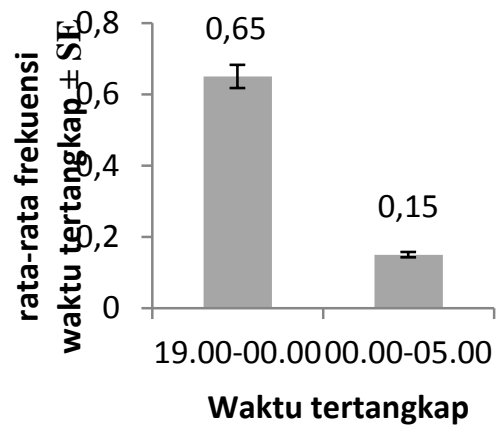

b. Umpan cacing tanah

Gambar 9 Frekuensi waktu tertangkapnya ikan kerapu dengan menggunakan umpan ikan tembang dan cacing tanah 
4. Frekuensi waktu tertangkap ikan terapon

Ikan terapon memperoleh hasil tangkapan terbanyak pada pukul 19.00-00.00 dengan nilai ratarata \pm SE adalah 0.7 ekor \pm 0.25 pada umpan ikan tembang dan umpan cacing tanah tangkapan terbanyak pada pukul 19.00-00.00 WIB dengan nilai rata-rata \pm SE adalah 0.65 ekor \pm 0.18 .

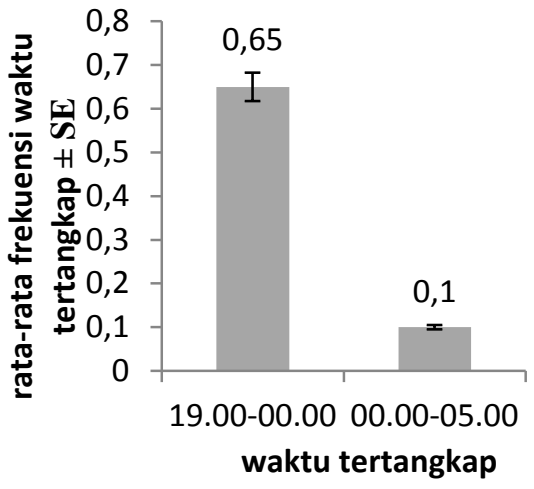

b. Umpan cacing tanah

Gambar 10 Frekuensi waktu tertangkapnya ikan kerapu dengan menggunakan umpan ikan tembang dan cacing tanah

\section{SIMPULAN}

1. Komposisi total hasil tangkapan pada alat tangkap pancing ulur terdiri dari 9 jenis ikan yaitu ikan kuwe (Caranx sp) dengan jumlah hasil tangkapan total 67 ekor, kakap (Lutjanus sp) 26 ekor, kerapu (Epinephelus pachycentru) 20 ekor, terapon (Terapon jarbua) 29 ekor, kapas-kapas (Geres punctatus) 14 ekor, kurisi (Nemipterus hexodon) 13 ekor, swanggi (Priacanthus tayanus) 7 ekor, sidat (Anguila marmorata) 2 ekor dan selar bentong (Selar crumenophthalmus).

2. Ikan hasil tangkapan dominan terdiri dari 4 jenis ikan yaitu ikan kuwe (Caranx sp) sebanyak 49 ekor untuk umpan ikan tembang dan 18 ekor untuk umpan cacing tanah. Ikan kakap sebanyak 8 ekor untuk umpan ikan tembang dan 18 ekor untuk umpan cacing tanah. Ikan kerapu sebanyak 4 ekor untuk umpan ikan tembang dan 16 ekor untuk umpan cacing tanah. Ikan terapon sebanyak 14 ekor untuk umpan ikan tembang dan 15 ekor untuk umpan cacing tanah.

3. Umpan ikan tembang dan umpan cacing tanah berbeda nyata terhadap hasil tangkapan.

4. Waktu yang paling baik untuk menangkap ikan kuwe, kakap, kerapu dan terapon yaitu pada pukul 19.00-00.00 WIB karena memberikan hasil tangkapan yang dominan dibandingkan pukul 00.00-05.00 WIB.

\section{DAFTAR PUSTAKA}

[PRTK] Pusat Riset Teknologi Kelautan. 2004. Laporan Survei Oseanografi Dalam Rangka Pengembangan Industri Air Laut dalam ( Deep Sea Water) Di Pelabuhan Ratu. Pusat Riset Teknologi Kelautan.
Fazri. 2014. Penggunaan Cacing Tanah (Lumbricus rubellus) Sebagai Umpan Alternatif Pancing Ulur (Hand line) Di Teluk Palabuhanratu [Skripsi].Bogor ID: Departemen Pemanfaatan Sumberdaya Perikanan, Fakultas Perikanan dan Ilmu Kelautan, Institut Pertanian Bogor.

Gunarso, W. 1985. Suatu Pengantar Tentang Tingkah Laku Ikan Terutama Dalam Hubungannya Dengan Alat, Metode Dan Taktik Penangkapan. Fakultas Perikanan IPB. Bogor. 142 hal.

Hendrotomo M. 1989. Studi Analisa Hasil Tangkapan Dengan Menggunakan Umpan Yang Berbeda Pada Rawai Cucut (Hiu) Permukaan Pelabuhan Ratu [skripsi]. Bogor: Fakultas Perikanan dan Ilmu Kelautan. Institut Pertanian Bogor. Bogor.

Walpole, R.E. 1995. Pengantar Statistika. PT. Gramedia Pustaka Utama: Jakarta.515 halaman.

Zulkarnain. 2011. Efektivitas Bubu Lipat Modifikasi dan Penggunaan Cacing Tanah (Lumbricus rubellus) Sebagai Umpan Alternatif Untuk Penangkapan Spiny Lobster (Panulirus sp) di Perairan Pesisir Timur Teluk Palabuhanratu Jawa Barat. Buletin PSP 19 (3 